\title{
Antibiotic Sensitivity for Ready-to-Eat Fish-Based Food-Borne Bacterial Pathogens
}

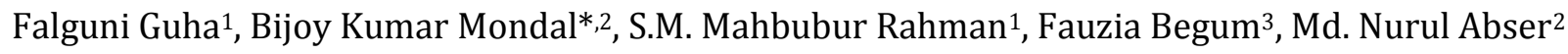 \\ ${ }^{1}$ Biotechnology and Genetic Engineering Discipline, Khulna University, Khulna - 9208, Bangladesh. \\ ${ }^{2}$ Department of Chemistry, Jahangirnagar University, Savar, Dhaka - 1342, Bangladesh. \\ ${ }^{3}$ Ex-Principal Scientific Officer, Food Microbiology Section, Institute of Food Science \& Technology (IFST), Bangladesh Council of Scientific \& Industrial Research \\ (BCSIR), Dr Qudrat-e-Khuda Road, Dhaka - 1205, Bangladesh.
}

\section{A R T IC LE DET A ILS}

\section{Article history:}

Received 29 June 2020

Accepted 18 July 2020

Available online 03 August 2020

\section{Keywords:}

Fish-Based Food

Bacterial Pathogens

Antibiotic Sensitivity

\begin{abstract}
A B S T R A C T
For the degradation of fish-based foods that consumed without any further processing, microbes play an important role. Proper knowledge of microbiological conditions can ensure quality food products that can save from foodborne diseases. The present study was carried out to investigate the microbiological quality of 30 ready-to-eat fish-based foods. The results exposed that the highest standard plate count (SPC) was $3.986 \times 10^{3} \mathrm{CFUg}^{-1}$. Hence, the analyzed samples were of acceptable microbial quality based on the total aerobic bacterial count. On the contrary, about $20 \%$ of food samples were identified as inappropriate because of containing fecal coliform. Salmonella spp. was not detected in any of the investigated samples. Six antibiotics namely tetracycline hydrochloride, erythromycin, amoxicillin, chlorpheniramine maleate, cephalexin, and ciprofloxacin were employed for susceptibility testing. Among the tested antibiotics, tetracycline hydrochloride and ciprofloxacin showed $87-100 \%$ susceptibility at the concentration of $240 \mu \mathrm{g} / \mathrm{mL}$. In the same concentration cephalexin showed $78 \%$ but other three antibiotics showed very less susceptibility against ready-to-eat fish-based food born bacterial pathogens.
\end{abstract}

\section{Introduction}

From ancient times, fish and fish-based foods are the major food components because of their easy digestibility and high nutritional value [1]. Bangladesh is one of the world's leading fish producing countries with a total production of an average 3.68 million metric tons per year. Almost $60 \%$ of protein are consumed by the people of Bangladesh generally comes from fish [2]. This sector is contributing significantly to food security through providing safe and quality protein [3]. The nutritional value of fish-based foods is distinguishable because of availability of proteins, unsaturated fatty acids, as well as certain minerals and vitamins in fish. Mainly, fish-based foods are deliberated as a very important source of n-3 polyunsaturated fatty acids (PUFA), especially eicosapentaenoic acid (EPA, C20:5n-3) and docosahexaenoic acid (DHA, C22:6n-3) [4,5]. The skin, gills, digestive tract, and light-emitting organs of fish contain bacterial populations [6,7]. Fecal coliform is a part of the total coliforms which is defined as Gram-negative, non-spore forming rods that ferments lactose at $44.5 \pm 0.2{ }^{\circ} \mathrm{C}$ within $24 \pm 2$ hours with the production of acid and gas. Fecal coliform i.e. E. coli is a usual inhabitant of the intestinal tract of humans and other warm-blooded animals. On the other hand, nonfecal coliforms i.e. enterobacter aerogenes are widely distributed in nature and found in soil, water, grains in addition to the intestinal tract of humans and other warm-blooded animals [8]. Fish and fish-based food products can be spoiled by a variety of bacteria, viruses, and parasites including Vibrio, Aeromonas, Flavobacterium, Yersinia, Edwardsiella, Streptococcus, lactococcus, Renibacterium, Mycobacterium, etc. [9]. The potential sources for contamination of fish products are water, air, humans, microbes in fish, processing equipment of food and other ingredients, product to product and contamination of microbes from the poor manufacturing process, etc. $[10,11]$

In recent years' numerous attempts have been taken to assure safe food. Results showed that the quality of food depends on the quantity of the total and thermotolerant coliforms, Staphylococcus aureus, Salmonella, Listeria monocytogenes, mesophile aerobic microorganisms, etc. The presence of such pathogenic microorganisms decreases the lifetime of foods $[12,13]$.

Most of the time consumers are not aware of the safety, quality, and hygiene of the ready-to-eat foods and face several uncontrolled food $n$ food-borne infectious intestinal diseases including diarrhea (with or without blood), dehydration, vomiting, fever, abdominal cramping, headache, myalgia, and arthralgia [14-17].

Antibiotics kill bacteria or resist them from copying themselves or reproducing to stop bacterial infections. Inappropriate use and overuse of antibiotics are key points of fuelling the emergence and spread of antibacterial resistant pathogens which can contaminate the food products, reach the human body and cause different problems to health [18]. The antibiotic selectivity should be a household term acknowledged by policymakers, academia, industry, and the public. Because the appropriate use of antibiotics for targeted microbes is essential for healthcare systems, patients, and society [19].

The present investigation has been undertaken to assess the microbiological quality of fish-based foods served in different restaurants of Dhaka city, Bangladesh. Objectives of the present studies are to enumerate total microbial counts in different fish-based foods and to clarify the antibiotic sensitivity of that isolated microbes against different antibiotics.

\section{Experimental Methods}

\subsection{Sampling}

Foods from four different areas at Dhaka city of Bangladesh identified as DA, DB, DC, and DE were selected. Ilish (Tenualosa ilisha), Mola (Amblypharyngodon microlepis), Baim (Mastacembelus armatus), Prawn (Penaeus monodon), Kai (Climbing perch), Tengra (Macrones vittalus), Puti (Puntius chola), Chapila (Gudusia chapra), Pomfret (Brama brama) and Taki (Channa punctata) had been selected for this work. Five fish base foods as fish curry, fish-based fast food, vegetable mixed fish curry, chopped fish, and dry fish curry were nominated for analysis. Different parameters were analyzed such as standard plate count, total coliform count, fecal coliform count, presence of Salmonella spp. etc. The bacteriological conditions of quality and safety were as described by the International Commission on Microbiological Specifications for Foods (ICMSF). 


\subsection{Microbiological Quality Assessment of the Samples}

The standard plate count (SPC) was obtained by the standard pour plate method using plate count agar (PCA) as the culture medium. This is a nonselective media for bacterial counting. In this experiment, a serial dilution was made up to $10^{-3}$ of the original sample using a Ringer solution as a diluting agent.

\subsection{Determination of Total Coliform Count}

The most probable number method (MPN) was used for the determination of coliform count. The flow chart (Fig. 1) explains the procedure of the determination of the total coliform count.

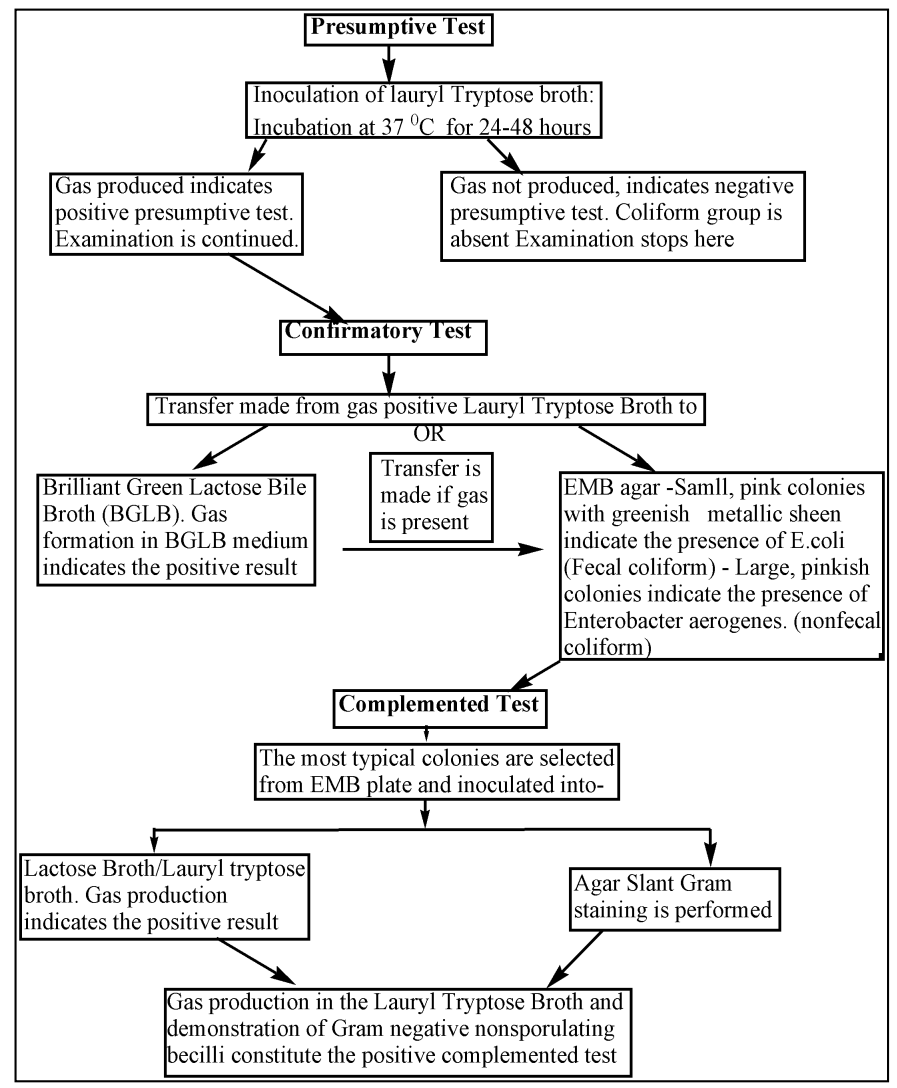

Fig. 1 Flowchart for determination of total coliform count

\subsection{Count of Fecal Coliforms}

Although the fecal coliform count can be determined primarily from EMB plate during the total coliform count, further confirmation was done by MPN method using selective media at a higher temperature. A loopful inoculum from each of the gas positive Lauryl Tryptose Broth was transferred to the fermentation tubes containing EC broth $(5 \mathrm{~mL}$ of 10 $\mathrm{mL} /$ tube). Then inoculated tubes were incubated at $44.5 \pm 0.2{ }^{\circ} \mathrm{C}$ for $24 \pm 2$ hours. The fecal coliform count was obtained by combining turbidity and gas production tubes with the statistical MPN-table.

\subsection{Qualitative Detection of Salmonella spp.}

Lactose broth was used as the pre-enrichment media and second step one milliliter of pre-enrichment culture was transferred to $10 \mathrm{~mL}$ of sterile selenite cystine broth medium, and then incubated at $37{ }^{\circ} \mathrm{C}$ for 24 hours. Finally, by streaking the loopful of enriched culture on to bismuth sulfite agar and incubated at $37{ }^{\circ} \mathrm{C}$ for $24-48$ hours. But no growth occurred in samples.

\subsection{Antibiotic Sensitivity of Different Isolates}

Six antibiotics viz. tetracycline hydrochloride, erythromycin, amoxicillin, chlorpheniramine maleate, cephalexin, and ciprofloxacin were used for sensitivity testing on the bacterial species, isolated as contaminants of fish-based food products.

The antibiotics were dissolved at the concentration of $240 \mu \mathrm{g} / \mathrm{mL}, 120$ $\mu \mathrm{g} / \mathrm{mL}$ and $60 \mu \mathrm{g} / \mathrm{mL}$. The isolated microbes were diluted to $10^{-2}$ cells $/ \mathrm{mL}$. One $\mathrm{mL}$ of diluted microbes is added to the malted Mueller Hinton Agar. The medium was plated and after solidification the porcelain beads were impregnated with antibiotic solution and placed up to the plates [20-22]. And incubated for $24 \mathrm{hrs}$. for producing zone of inhibition.

https://doi.org/10.30799/jpmr.046.20050102

\section{Results and Discussion}

\subsection{Microbiological Quality Analysis}

Fish base foods play an important role to satisfy the demand of protein, lipids as well as essential micronutrients as Vitamin D, selenium, phosphorus, calcium, etc., [23]. Contaminated with foodborne pathogens can degrade the foods easily and become inedible. The presence of different bacteria species including human pathogenic bacteria in fish can be directly linked to human health. Thus, the detection of hazardous microbes is important to optimize product quality and ensure safe foods.


Fig. 2 Microbial populations of ready-to-eat fish-based food samples (a) fish curry samples and (b) fish-based fast food samples

Fig. 2 ( $a$ and b) and Table 1 represents the total aerobic bacterial count (TABC) by standard plate count (SPC). Fig. 2(a) shows that the fish curry samples have recorded a range of $0.67 \times 10^{2}$ to $3.986 \times 10^{3} \mathrm{CFUg}^{-1}$. The highest and lowest SPC were noted for puti fish curry and Prawn curry of DA and DE area respectively. Maximum of the curry samples contained around $2.5 \times 10^{2} \mathrm{CFUg}^{-1}$. Fig. 2(b) shows that the fish-based fast food samples have recorded a range $0.35 \times 10^{2}$ to $2.000 \times 10^{3} \mathrm{CFUg}^{-1}$. The highest SPC was found for the fish cutlet of DA area. Table 1 shows the standard plate count (SPC) of fish mixed vegetables, chopped fish, and sundried fish with vegetable samples. Result notifies that these samples contain a range $0.55 \times 10^{2}$ to $1.338 \times 10^{3} \mathrm{CFUg}^{-1}$. Only one sample (chopped prawn) reported over $10^{3} \mathrm{CFUg}^{-1}$.

Table 1 Microbial populations of fish mixed vegetable, chopped fish and sundried fish with vegetable samples

\begin{tabular}{llll}
\hline & Name of the sample & Area & Log $\left(\mathrm{CFUg}^{-1}\right)$ \\
\hline \multirow{4}{*}{ Vegetable } & Fish vegetable & DB & 2.58 \\
& Prawn with vegetable & DC & 1.40 \\
& Prawn with vegetable & DE & 2.94 \\
& Prawn with potato & DB & 2.85 \\
\hline \multirow{3}{*}{ Chopped } & Chopped Prawn & DB & 3.13 \\
& chopped Taki fish & DC & 2.20 \\
& Prawn with vegetable & DE & 2.95 \\
\multirow{2}{*}{ Dry fish } & Dried laitka curry & DC & 2.99 \\
& Dried small fish curry & DC & 2.50 \\
& Dried Pomfret curry & DC & 2.47 \\
\hline
\end{tabular}

Table 2 represents the total coliform count and total fecal coliform count enumerated from 30 ready-to-eat fish-based food samples at four different phases of the processing line. This result shows that total 
coliform counts were identified by about $50 \%$ of samples. The highest $62.5 \%$ samples of DB and DC area were spotted the total coliform count. Only $33.33 \%$ samples of DE area were detected the total coliform count. About $20 \%$ of food samples were noticed with fecal coliform at a range of $0.05-0.2 \mathrm{MPN} \mathrm{g}^{-1}$.

Table 2 The total coliform count and faecal coliform tallied from fish-based food samples

\begin{tabular}{|c|c|c|c|}
\hline $\begin{array}{l}\text { Sampling area } \\
\text { (code) }\end{array}$ & Name of the sample & $\begin{array}{l}\text { Total coliform } \\
\text { count }\left(\mathrm{MPNg}^{-1}\right)\end{array}$ & $\begin{array}{l}\text { Fecal coliform } \\
\text { count }\left(\mathrm{MPNg}^{-1}\right)\end{array}$ \\
\hline \multirow{6}{*}{ DA } & Tangra fish curry & 1.4 & N.F \\
\hline & Puti fish carry & N.F & N.F \\
\hline & Ilish curry & 0.75 & N.F \\
\hline & Prawn fry & N.F. & N.F. \\
\hline & Fish fry (slice) & N.F. & N.F. \\
\hline & Prawn chop & 0.1 & N.F. \\
\hline \multirow{8}{*}{ DB } & Fish cutlet & 0.55 & 0.1 \\
\hline & Fish fry (Coated) & N.F. & N.F. \\
\hline & Fish finger & 1.05 & N.F \\
\hline & Pomfret fry & 0.09 & N.F \\
\hline & Pomfret fry (2) & N.F. & N.F. \\
\hline & Fish finger & N.F & N.F \\
\hline & Fish vegetable & 0.55 & N.F \\
\hline & Prawn with vegetable & 0.6 & N.F \\
\hline \multirow{8}{*}{ DC } & Ilish curry & 0.18 & 0.2 \\
\hline & Mola curry & 0.34 & 0.1 \\
\hline & Chapila fish curry & N.F. & N.F \\
\hline & Prawn with vegetable & 0.1 & N.F \\
\hline & Chopped taki fish & 0.7 & 0.05 \\
\hline & Dried mola curry & 0.7 & 0.05 \\
\hline & Dried Pomfret curry & N.F. & N.F. \\
\hline & Prawn curry & N.F. & N.F. \\
\hline \multirow{10}{*}{$\mathrm{DE}$} & Prawn with Potato & N.F. & N.F. \\
\hline & Baim fish curry & N.F. & N.F \\
\hline & Kai fish curry & N.F. & N.F \\
\hline & Kai fish curry(2) & 0.5 & N.F. \\
\hline & Baim fish curry & N.F. & N.F \\
\hline & Taki fish curry & N.F & N.F \\
\hline & Prawn with vegetable & 0.2 & 0.05 \\
\hline & Chopped Prawn & 0.05 & N.F \\
\hline & Chopped mola fish & N.F. & N.F \\
\hline & Total-30 & & \\
\hline
\end{tabular}

Four fish samples in raw, cooked, and frozen condition contain up to $10^{6}$ $\mathrm{CFU} / \mathrm{mL}$ of total viable bacteria count (TVC). The raw fish samples were mostly found to harbor a huge population of microorganisms up to $10^{5}$ $\mathrm{CFU} / \mathrm{mL}$ including the fecal coliforms [24]. Furthermore, different types of specific bacterial species, for example E. coli, Staphylococcus spp., Vibrio spp., Shigella spp., Salmonella spp., Pseudomonas spp. and Klebsiella spp. were also found in raw samples [25,26]. Salt dried marine fish samples were reported the total plate count (TPC) up to $5.3 \times 10^{6} \mathrm{CFU} \mathrm{g}^{-1}$ with a different group of faecal coliforms and Vibrio spp. is an alarming situation [27]. Ready-to-eat food of Siu Mei and Lo Mei shops in Hong Kong was found SPC ranging from 1.97 to $6.84 \log C F U g^{-1}$, with a mean of $5.05 \mathrm{log}$ $\mathrm{CFUg}^{-1} ;$ E. coli counts ranging from none detected to $3.10 \log _{\mathrm{CFUg}}{ }^{-1}$, with a mean of $1.78 \log _{\text {CFUg- }}{ }^{-1}$; and $S$. aureus counts ranging from none detected to $1.42 \log _{\mathrm{CFUg}}{ }^{-1}$, with a mean of $0.15 \log _{\mathrm{CFUg}}{ }^{-1}$ [28]. Ready-to-serve food samples were found as inappropriate according to Microbiological Criteria Regulation because of having L. monocytogenes, B. cereus, E. coli, etc. [29]. The maximum recommended bacterial counts for ready-to-eat good quality products is $<10^{3}$ whereas $10^{3}$ to $<10^{4} \mathrm{CFUg}^{-1}$ is acceptable quality foods. But the more than $10^{4} \mathrm{CFUg}^{-1}$ will be denoted as unsatisfactory class food $[30,31]$. The acceptable limit for the total coliform count and the total fecal coliform count is $<1 \mathrm{MPNg}^{-1}$ and not detected respectively [32]. In this research, $10 \%$ of curry samples and $40 \%$ fast food samples bring acceptable limits of aerobic colony counts. The rest of the samples contain satisfactory limits of aerobic colony counts. No sample was found the SPC value over $10^{4} \mathrm{CFUg}^{-1}$. Hence, these ready-to-eat fish-based food samples taken for microbial quality assessment were of acceptable microbial quality based on the total aerobic bacterial count. On the contrary, about $20 \%$ of food samples inappropriate for taking because of containing Fecal coliform. No sample out of 30 was detected Salmonella spp.

\subsection{Antibiotic Susceptibility Pattern}

Cautious implementation of antibiotics can prevent the resistance of anti-bacterial pathogens which is very harmful to the human body and cause different problems to health. Table 3 represents the antibiotics susceptibility of ready-to-eat fish-based food born bacterial pathogens. https://doi.org/10.30799/jpmr.046.20050102
Results showed that very negligible sensitivity was recorded for chlorpheniramine maleate group antibiotics.

Table 3 The zone of inhibition produced by the antibiotics

\begin{tabular}{lllll}
\hline Trade name & The chemical name & Susceptibility $(\%)$ & \\
\hline & & $240 \mu \mathrm{g} / \mathrm{mL}$ & $120 \mu \mathrm{g} / \mathrm{mL}$ & $60 \mu \mathrm{g} / \mathrm{mL}$ \\
\hline Terax & $\begin{array}{l}\text { Tetracycline } \\
\text { Hydrochloride }\end{array}$ & 86.67 & 80.00 & 74.50 \\
& $\begin{array}{l}\text { Erythromycin } \\
\text { Erocin }\end{array}$ & 8.00 & 0.00 & - \\
Amoxicillin & $\begin{array}{l}\text { Amoxicillin } \\
\text { Eramin }\end{array}$ & 33.34 & 20.00 & 0.00 \\
& $\begin{array}{l}\text { Cholorpheniramine } \\
\text { maleate }\end{array}$ & 6.66 & - & - \\
Acelex & $\begin{array}{l}\text { Cephalexin } \\
\text { Cipronil }\end{array}$ & 78.25 & 40.00 & 25.00 \\
\hline
\end{tabular}

The highest susceptibility was found for ciprofloxacin about 100\% (Fig. $3)$. An experiment was conducted using three concentrations of ciprofloxacin antibiotic (60 $\mu \mathrm{g} / \mathrm{mL}, 120 \mu \mathrm{g} / \mathrm{mL}$, and $240 \mu \mathrm{g} / \mathrm{mL})$ in the same dish with impregnated of porcelain beads. Results showed that all concentrations performed almost similarly.

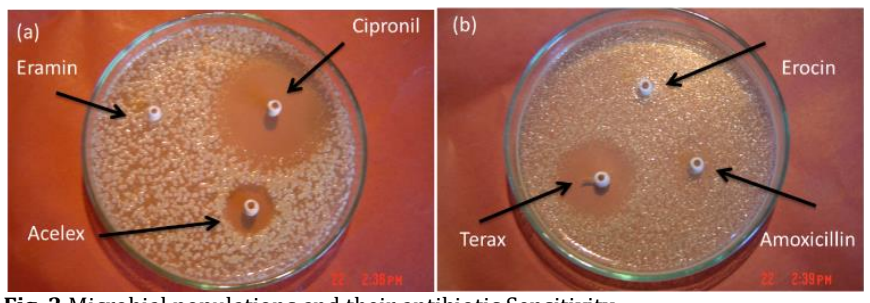

Fig. 3 Microbial populations and their antibiotic Sensitivity

It can be concluded that the $60 \mu \mathrm{g} / \mathrm{mL}$ dosage of ciprofloxacin is sufficient for ready-to-eat fish-based food born bacterial pathogens. Similar information was given by De Bruyn et al., [33]. They informed that a single dose of a fluoroquinolone (eg, ciprofloxacin, $500 \mathrm{mg}$ ) was effective in the treatment of traveler's diarrhea. Azage et al., reported that many types of bacterial isolates were resistant to tetracycline, cotriamoxazole, and erythromycin whereas many of them were sensitive to chloramphenicol, nalidixic acid, gentamicin and ciprofloxacin [34].

\section{Conclusion}

The presence of the pathogenic bacteria and biochemical parameters such as histamine risk might be a problem in fish-based food products. This paper introduces an assessment scheme for better evaluation of various microbiological qualities, hygiene, and safety parameters of readyto-eat fish-based foods. Depending on total viable bacteria (TVC) $90 \%$ curry samples and $60 \%$ fast food samples bring satisfactory limits of aerobic colony counts. The rest of the samples contains acceptable limits of aerobic colony counts. About $20 \%$ of food samples unsuitable for taking because of having Fecal coliform. Among six antibiotics highest susceptibility was found for Ciprofloxacin (100\%) and Tetracycline Hydrochloride $(86.66 \%)$ for ready-to-eat fish-based food born bacterial pathogens.

\section{Acknowledgments}

The authors wish to thank the Institute of Food Science \& Technology (IFST), Bangladesh Council of Scientific \& Industrial Research (BCSIR), Dr. Qudrat-e-Khuda Road, Dhaka 1205, Bangladesh and Biotechnology and Genetic Engineering Discipline, Khulna University, Khulna-9208, Bangladesh to give the opportunity and financial support for the research.

\section{References}

[1] K. Parvathi, J. Karthegaa, Analysis of total microbial count in the gut of fresh water fish Cyprinus carpio fed with isolated probiotics, Int. J. Adv. Res. Biol. Sci. 4 (2017) 169-172.

[2] M.A. Hussain, M.L. Kabir, M.A. Sayeed, A. Mahbub-E-Elahi, M.S. Ahmed, M.J. Islam, Organochlorine pesticide residues and microbiological quality assessment of dried barb, Puntius sophore, from the Northeastern Part of Bangladesh, Fishes 3 (2018) 44:1-12.

[3] M.M. Shamsuzzaman, M.M. Islam, N.J. Tania, M.A. Al-Mamun, P.P. Barman, X. Xu, Fisheries resources of Bangladesh: Present status and future direction, Aquacult. Fish. 2 (2017) 145-156.

[4] R. Branciari, R. Franceschini, R. Roila, A. Valiani, I. Pecorelli, et al., Nutritional value and contaminant risk assessment of some commercially important fishes 
and crawfish of Lake Trasimeno, Italy, Int. J. Environ. Res. Public. Health. 17 (2020) 2545:1-14.

[5] J. Pradeepkiran, Aquaculture role in global food security with nutritional value: a review, Transl. Anim. Sci. 3 (2019) 903-910.

[6] B. Austin, The bacterial microflora of fish, Sci. World. J. 2 (2002) 558-572

[7] P.S. Sudheesh, A. Al-Ghabshi, N. Al-Mazrooei, S. Al-Habsi, Comparative pathogenomics of bacteria causing infectious diseases in fish, Int. J. Plant. Dev. Biol. 1 (2012) 16:1-16.

[8] M. Seo, H. Lee, Y. Kim, Relationship between coliform bacteria and water quality factors at weir stations in the Nakdong River, South Korea, Water 11 (2019) 1171:1-16.

[9] E. Kuley, M. Durmus, E. Balikci, Y. Ucar, J.M. Regenstein, F. Ozogul, Fish spoilage bacterial growth and their biogenic amine accumulation: Inhibitory effects of olive by-products, Int. J. Food Prop. 20 (2017) 1029-1043

[10] I.A. Rather, W.Y. Koh, W.K. Paek, J. Lim, The sources of chemical contaminants in food and their health implications, Front. Pharmacol. 17 (2017) 830:1-8.

[11] A. Novoslavskij, M. Terentjeva, I. Eizenberga, O. Valcina, V. Bartkevics, A. Berzins, Major foodborne pathogens in fish and fish products: a review, Ann. Microbiol. 66 (2015) 1-15.

[12] D.F. Klingbeil, M. Murtada, V. Kuri, E.C. Todd, Understanding the routes of contamination of ready-to-eat vegetables in the Middle East, Food Control 62 (2016) 125-133.

[13] V. Schuh, J. Schuh, N. Froza, F.B. Foralosso, S. Verruck, et al., Evaluation of the microbiological quality of minimally processed vegetables, Food Sci. Technol. 40 (2020) 290-295.

[14] D.G. Newell, M. Koopmans, L. Verhoef, E. Duizer, A. Aidara-Kane, et al., Foodborne diseases - the challenges of 20 years ago still persist while new ones continue to emerge, Int. J. Food Microbiol. 139 (2010) S3-S15.

[15] M.M.C. Feltes, A.P. Arisseto-Bragotto, J.M. Block, Food quality, food-borne diseases, and food safety in the Brazilian food industry, Food Quality Safety 1 (2017) 13-27.

[16] T.L. Switaj, K.J. Winter, S.R. Christensen, Diagnosis and management of foodborne illness, Am. Fam. Physician. 92 (2015) 358-365.

[17] A. Koluman, A. Dikici, Antimicrobial resistance of emerging foodborne pathogens: Status quo and global trends, Crit. Rev. Microbiol. 39 (2012) 57-69.

[18] R. Canton, J.P. Horcajada, A. Oliver, P.R. Garbajosa, J. Vila, Inappropriate use of antibiotics in hospitals: The complex relationship between antibiotic use and antimicrobial resistance, Enferm. Infecc. Microbiol. Clin. 31 (2013) 3-11.

[19] S.L. Lammie, J.M. Hughes, Antimicrobial resistance, food safety, and one health: The need for convergence, Annu. Rev. Food Sci. Technol. 7 (2016) 287-312.

[20] O. Muter, A. Mihailova, A. Berzins, K. Shvirksts, A. Patmalnieks, et al., Optimization of nitrification process by a bacterial consortium in the submerged biofiltration system with ceramic bead carrier, J. Microb. Biochem. Technol. 6 (2014) 148-153.

[21] A.W. Bauer, W.M.M. Kirby, J.C. Sherris, M. Turck, Antibiotic susceptibility testing by a standardized single disk method, Am. J. Clin. Pathol. 45 (1966) 493-496.

[22] V. Banik, M. Abony, S. Datta, S.T. Towhid, Microbiological quality of ready -to eat food from Dhaka, Bangladesh, Curr. Res. Nutr. Food Sci. 7 (2019) 161-168.

[23] S.K. Tilami, S. Sampels, Nutritional value of fish: lipids, proteins, vitamins, and minerals, Rev. Fish. Sci. Aquac. 26 (2017) 243-253.

[24] M.R. Atanassova, M.J. Chapela, A. Garrido-Maestu, P. Fajardo, M. Ferreira, et al., Microbiological quality of ready-to-eat pickled fish products, J. Aquat. Food Prod. Technol. 23 (2014) 498-510.

[25] H.W. Kim, Y.J. Hong, J.I. Jo, S.D. Ha, S.H. Kim, et al., Raw ready-to-eat seafood safety: microbiological quality of the various seafood species available in fishery, hyper and online markets, Lett. Appl. Microbiol. 64 (2016) 27-34.

[26] I.T. Nur, A.N. Mou, U. Habiba, Comparative microbiological analysis of four different sea fishes collected from local market in Dhaka Metropolis, Food Res. 4 (2019) 161-165.

[27] A.R. Logesh, M. Pravinkumar, S.M. Raffi, M. Kalaiselvam, An investigation on microbial screening on salt dried marine fishes, J. Food Resour. Sci. 1 (2012) 15-21.

[28] Y.F. Ng, S.L. Wong, H.L. Cheng, P.H.F. Yu, S.W. Chan, The microbiological quality of ready-to-eat food in Siu Mei and Lo Mei shops in Hong Kong, Food Control 34 (2013) 547-553.

[29] R.J. Meldrum, P.T. Mannion, J. Garside, Microbiological quality of ready-to-eat food served in schools in Wales, United Kingdom, J. Food Prot. 72 (2009) 197 201.

[30] M. Armani, M. Civettini, G. Conedera, M. Favretti, D. Lombardo, et al., Evaluation of hygienic quality and labelling of fish distributed in public canteens of northeast Italy, Ital. J. Food Saf. 5(4) (2016) 5723:185-190.

[31] G. Abakari, S.J. Cobbina, E. Yeleliere, Microbial quality of ready-to-eat vegetable salads vended in the central business district of Tamale, Ghana, Food Contam. 5 (2018) 3:1-9.

[32] N.M. Nespolo, T.M. Martineli, O.D. Rossi, Microbiological quality of salmon (Salmo salar) sold in cities of the state of SaO Paulo, Brazil, Braz. J. Microbiol. 43 (2012) 1393-1400.

[33] G. De Bruyn, S. Hahn, A, Borwick, Antibiotic treatment for travellers' diarrhea Cochrane Database Syst. Rev. 3 (2000) CD002242:1-29.

[34] A. Amare, T. Worku, B. Ashagirie, M. Adugna, A. Getaneh, M. Dagnew, Bacteriological profile, antimicrobial susceptibility patterns of the isolates among street vended foods and hygienic practice of vendors in Gondar town Northwest Ethiopia: a cross sectional study, BMC Microbiol. 19 (2019) 120:19. 